\title{
SOCIAL SCIENTISTS FROM THE LEFT-WING PARTY AND DISCUSSIONS ABOUT POWER IN CHILE (1970 - 1973) ${ }^{1}$
}

Cientistas sociales de izquierda y las discusiones sobre el poder en Chile (1970 - 1973)

\author{
Ivette Lozoya*
}

\begin{abstract}
The following article analyzes the discussions about the power given to the Latin American sociologists and economists as well as Latin Americanists established in Chile during the Unidad Popular government. This paper aims to establish whether the decisive political process experienced between 1970 and 1973 allowed the social scientists that lived it to contribute to the theory of power, questioning the Dual Power category and developing the People Power theory.

Keywords: Social scientists, power, People Power, Marxism.

\footnotetext{
${ }^{1}$ Este artículo fue enviado a revisión inicialmente en español y ha sido traducido al inglés gracias al Proyecto FP150008, "Aumento y mejora del índice de impacto y de la internacionalización de la revista Universum por medio de la publicación de un mayor número de artículos en inglés". Fondo de Publicación de Revistas Científicas 2015, Programa de Información Científica, Comisión Nacional de Investigación Científica y Tecnológica (Conicyt), Chile.
}

This paper was initially sent for review in Spanish, and it has been translated into English with the support of the Project FP150008, "Aumento y mejora del índice de impacto y de la internacionalización de la revista Universum por medio de la publicación de un mayor número de artículos en inglés." Fund for publication of Scientific Journals 2015, Scientific Information Program, Scientific and Technological Research National Commission (Conicyt), Chile.

* Facultad de Humanidades, Departamento de Historia, Universidad de Santiago de Chile. Santiago, Chile. Correo electrónico:Ivette.lozoya@usach.cl

Artículo recibido el 31 de marzo de 2016. Aceptado el 20 de abril de 2016.
\end{abstract}




\section{RESUMEN}

El siguiente artículo se propone analizar las discusiones sobre el poder dadas por los sociólogos y economistas latinoamericanos y latinoamericanistas radicados en Chile durante el gobierno de la Unidad Popular. Este trabajo tiene como objetivo establecer si el álgido proceso político vivido entre 1970 y 1973 permitió a los cientistas sociales que lo vivían, aportar a la teoría del poder poniendo en tensión la categoría de Poder Dual y elaborando la de Poder Popular.

Palabras clave: Cientistas sociales, poder, Poder Popular, Marxismo.

The eternal need for transformation in Latin America was accompanied in the sixties by the possibility of the revolution that opened the Cuban process, each country attempting their own. In Chile in 1970, stressed by internal conflicts but also influenced by the continental mood, the progression of a political leftward movement was experienced, which allowed the reformism of Frei's government to be defeated; the triumph of the Unidad Popular (Popular Unity) was presented as a transition to socialism, the creation of parties or lines inside the left-wing politics that ascribed to the armed struggle and the construction of the basis of a significant popular movement ${ }^{2}$.

The intellectual field had accumulated a great amount of social scientists that were attracted by the development of an important academic institutionalization; they had settled mainly in Santiago and Concepción. The political process also turned out to be attractive to the renowned academics since they were able to contribute to the process in an atmosphere of plurality, without censorship, similar to the European democracies (Pico, Pecourt, 2013). Finally, the newly settled dictatorships in Argentina and Brazil expelled from their countries an important group of consolidated or in training intellectuals that, by the characteristics described above, ended up choosing Chile to live their exile (Lozoya, 2013).

In this intense political context, the Chilean Latin American social scientists and Latin Americanists who identified themselves with the left-wing party lived through the transformation process in Chile and discussed power, strategy and revolution. These discussions were intensified during the government of Allende, especially after the display of conservative decisions made by the end of his first year in office.

The intellectuals that we are talking about are those militants or supporters of the Communist and Socialist Party, the Movimiento de Acción Popular Unitaria (Movement of United Popular Action) (Mapu) and the Movimiento de Izquierda

\footnotetext{
${ }^{2}$ I appreciate the comments and contributions of Prof. Eduardo Devés.
} 
Revolucionaria (Movement of the Revolutionary Left-Wing) (MIR). All of them had dual requirements, on one side, the context of accelerating events, and on the other side, the expectations of their parties and their own in regards to the role that intellectuals should play during the transformation process.

Regarding this last point, the self-perception of the Marxist parties' social scientists as revolutionary intellectuals was mediated by the theory that Lenin, Rosa Luxemburg and Gramsci had already put forward, thus creating differences among them in respect to their social role and job inside the party. While communists adopted a propagandist position of the process, seeking to incorporate the awareness of classes from the outside as proposed by Leninism, a segment of the socialists and MIRists was more aligned with Luxemburg's theory, attempting a direct link with the class by theorizing their practices. Thus, the intellectuals would argue and theorize in regards to their role as researchers and academics answering the demands of their parties while trying to contribute to the complex scenario where they were operating.

In the period of time that we are analyzing, there were several Marxist economic-social scientists residing in Chile, of those, there are some that precisely argued about the issues of power from their role as intellectuals. In the present paper, we will specifically highlight the Brazilians Theotonio Dos Santos, Ruy Mauro Marini, the Peruvian Aníbal Quijano, the Bolivian René Zabaleta and the Chileans Marta Harnecker, Kalki Glauser, José Antonio Viera Gallo and the Argentineans Nestor D'Alessandro and Juan Carlos Martí. In regards to them, we can say that in general, they fulfill the professional definition of an intellectual, but not all of them are academics of high impact in the public domain. Some of them were only known in their restricted environments of work and militancy.

Therefore, we will analyze them by two considerations, first, all of them are economic-social scientists, and second, all of them participated in the public political discussion with their professional knowledge, independent of the impact that their contributions may have had in that period or wider circles.

Thus, we consider these social scientists as intellectuals as long as they participated in a discussion and contributed from their specific social role, but this discussion is performed in a public space that goes well beyond the limited area of academic discussions.

Additionally, keeping in mind the political demands that the setting asked of intellectuals, several of them occupied "very practical" roles in the process, either because they were intended to occupy public offices or because they actively participated in the process of political leadership of the masses, thus, it is necessary to notice that, independent of their specific social role in this historical period, it is difficult to differentiate the action and political reflection of the purely intellectual contribution of those that are analyzed. 
The social scientists that we are referring to said and acted from the study centers created in that time, through written forms of communication, within the government positions that they occupied and from their parties. From there, they characterized the Chilean reality and tried to project it starting from a premise that at the end would prove to be false, that capitalism was living a deadly crisis and that humankind was inevitably moving towards socialism. Under this premise, they analyzed the Dual Power theory, assessed the limits of the power of the bourgeois state, and tried to analyze the experiences that, in their own opinion, were experiences of the construction of the People Power. Recognizing these intellectual and political efforts, we ask ourselves: Were the Marxist economic-social scientists living in Chile during the Unidad Popular able to contribute to the power theory? What were those contributions?

The context of analysis presents two issues that we have to consider when evaluating the contributions of the left-wing intellectuals: first, the economists, political scientists, and sociologists were theorizing an unprecedented reality of rapid transformation, and in second, the process is short and suddenly and violently stopped by the coup.

The intellectuals of that time -even beyond the social scientists that we are talking about- besides observing the difficulties of advancing socialism with a state apparatus caught within the limits of liberal democracy, they also observed the intuitive ${ }^{3}$ practices of social construction by workers, students and inhabitants. Placing their hopes in the latter, they defined them as seeds of People Power, assuming that the current task was to project that growing process. Thus, the role of the Marxist parties was to spearhead the process of progression and the role of the intellectuals that thought organically about the process was to systemize the practice and develop the People Power theory; however, both the parties and the organic-thinking intellectuals, far from bearing the role of leader in the process, what they did was analyzed and systematized the popular experience but without achieving the construction of a complex People Power theory that would guide the revolutionary leap.

\section{POWER THEORIES AND THE INTELLECTUAL AND HISTORICAL REFERENCES OF SOCIAL SCIENTISTS IN CHILE}

The parties and intellectuals of the marxist left-wing in Chile had two key historical references for analyzing the Chilean path, the first of them was the Russian

\footnotetext{
${ }^{3}$ In regards to intuitive practices, we are referring to the actions that do not adhere to a definite and closed theory but to creative practices that are often handled by political parties yet equally display originality and autonomy.
} 
Revolution, whose experience had been systematized by Lenin, giving origin to the theory of Dual Power; the second one was the Cuban experience, which had spread the theorization of the strategy for rising to power more widely. These two experiences were the mirror in which the Chilean reality looked into, but they still tried to construct themselves as a distinct entity. This observation, imitation and differentiation exercise would generate critics and contributions from the social scientists in Chile, as well as establish the differences among the social scientist themselves in regards to how to categorize and where to lead the Chilean process.

In the dialogue with Cuban reality and the political-theoretical discussions carried out by the social scientists, we can see that although the island had become an obligatory reference to the Latin American and Chilean revolutionaries, there was clarity about the differences in the process: the first that stood out was the criticism of the military strategy. Beyond the fact that an important group of the intellectuals that we are talking about accepted and promoted the use of armed forces, they did not consider Focalism as a formula; in second place, the opposition forces were alive and active in Chile, even though much of the left-wing had risen to power in the government, they did not possess control of the State that continued operating within the democratic-bourgeois rules. By then, Cuba was a reference but not a mirror and the theorization of their experience did not guide the local process. In this point, those who systematized the critical eye and theorized about the strategy were mainly the Brazilians residing academically in the CESO, Vania Bambirra and Theotonio Dos Santos, who wrote a couple of texts where they questioned Focalism. The text of Bambirra was based on the argument "Revolución Cubana una reinterpretación" (Cuban revolution, a reinterpretation), published by CESO-PLA in 1973, where she asserted the role of party leadership and urban centers in the development process of the armed fight ${ }^{4}$, while Dos Santos, in a FLACSO work document with the title Dependencia y Alternativa de cambio en América Latina (Dependency and Alternative of Change in Latin America) (CESO 1970) would warn that in Latin America existed the creation of a revolutionary strategy that was not Focalism, but in lack of a more proper conceptualization, the same revolutionaries qualified it as so, Dos Santos thus, proved the role of the intellectual in the process, achieving the categorization of the revolutionary experience happening and distinguishing them from the previous ones.

The second big reference, the Russian experience, was addressed in a less innovative way and much more like a model. The left-wing organizations and their

\footnotetext{
${ }^{4}$ Another fundamental text where the discussion is developed will be edited in two volumes by Bambirra, Álvaro López, Silvestre Condoruna (pseudonym of Aníbal Quijano), Rui Mauro Marini, among others, with the title: Diez años de insurrección en América Latina (Ten years of insurrection in Latin America), Ediciones Prensa Latinoamericana, Chile, 1971.
} 
intellectuals analyzed the problem of power in Chile from the theoretical basis of Marxism-Leninism, trying to recognize which were the divergent and convergent points with the historical process that lead to the theory, the Russian Revolution. Here it is necessary to point out that we will understand Marxism-Leninism in brief, that means, the observation that made Lenin about the Russian reality under the Marxist theory and the conceptualization of that reality under its particular interpretation that gave origin to a theory itself, the theory about power. The social scientists analyzed and compared the Chilean process with that experienced by Russia through the conceptualizations lifted by Lenin and became evident that although in Chile there existed working and territorial organization, these spaces had not achieved the same level of coordination and projection as the Soviets, which meant there still was not true pressure on the bourgeois institutionality that kept operating with the logics of democracy, trying to reconcile the interest of the reactionary bourgeois and the progress of popular actions. Thus, there were two positions among the parties and the left-wing intellectuality, to move forward from the top, changing the character of the State using the bourgeois institutionality, or moving forward from below, building People Power, allowing the upward mobilization of the people in a way that filled the State, giving into the revolutionary leap.

The intellectuals of the Marxist left-wing that assumed the first position were those linked to the Communist Party and the socialists of an Allende-like trend, while those aligned with the position of the revolutionary leap were the intellectuals linked to the MAPU ,Movimiento de acción Popular Unitaria (Movement of United Popular Action), to one of the sectors of the Socialist Party and to the Movimiento de Izquierda Revolucionaria (Revolutionary Left-wing Movement) (MIR). The discussions among them were carried out in academic conferences, in the journals Chile Hoy and Punto Final, and in the study centers of the Universidad Católica, Universidad de Concepción and Universidad de Chile. The final or partial conclusions remain printed in several publications of that time. Then at a theoretical level, we can identify two areas and levels in the discussion of the intellectuality about power, the first one concerned the assessments in regards to the State, its characteristics and role in the transition process to socialism. In this sense, the social scientists tried to learn about the experiences already lived by implementing the Power theory, while in the second one, reference was made to the composition and projection of what was denominated as People Power, in that level the social scientists observed the growth of that phenomenon, without having very precise references to guide the experience and therefore, trying to draw lessons from it.

In academic terms, the first discussion was developed in those study centers created in the process of professionalization of the Social Sciences in Chile, and that by 1970 had important researchers from all over the world, many of them 
influenced by the Marxist interpretative trend; we are referring to the study centers of the Universidad Católica and to the Universidad de Chile, CEREN and CESO, respectively. The intellectuals associated to those research spaces developed their own inquiries and theorizations separately, but had the possibility of discussing it between them and with other political and intellectual actors in a seminar called "Transición al socialismo y experiencia chilena" (Transition to socialism and the Chilean experience). In that meeting, held at the end of October in 1971, gave origin to a paper edited in 1972 that discussed the limits and possibilities of the State to develop the transition towards socialism.

The organizers recognized in the first pages of the publication what the experience of the Unidad Popular meant to the academic institutions and the challenge of "adapting their work to the demands of the social process, contributing from this point of view for its understanding" (Basso et al., 1972). The then activist of the MAPU and director of the CEREN, Manuel Antonio Garretón, and the socialist Roberto Pizarro, posed as problem that the conclusion derived from the meeting might be a bit outdated since they did not consider the events that happened in the last six months since the symposium was held until the publication was edited. This last observation is very important due to the evidence of the acceleration of time that Chile was experiencing and the urgency with which the intellectuality, and especially the social scientists, were facing the reality.

Those that participated in the first round table discussion called "La transición socialista y el problema del poder" (The socialist transition and the problem of power) were Lelio Basso, Kalki Glauser, Rossana Rossanda, Marta Harnecker and José Antonio Viera Gallo. For these political-intellectuals, in the Chile of the Unidad Popular, there existed a revolutionary process within an institutional, political and juridical framework of bourgeois character, in this context it was important to define the limits between reform and revolution and to understand the power of the State, that one year before the rise of Allende to the government, it still had not been modified.

Highlighted in the interventions of these intellectuals are the numerous references to the texts of Marx for justifying affirmations about what the historical moment was that Chile experienced, what was the social training present and how these characteristics were expressed. One of the coinciding elements was that there was no clarity about what the characteristics were of a society in transition towards socialism. This lack of certainty served everyone in agreement with the diverse political conceptions, identifying the characteristics of Chilean society that would allow the definition of it as a society in transition, establishing the potential and limitations of the process.

The text by Lelio Basso was presented in Italian and translated by the young political and intellectual of the MAPU, Kalki Glauser. In this text Basso proposed 
that the construction of socialism did not begin with the takeover of power, but culminated in that, thus, the class and power fight was also a fight for rights, that means for a new institutionality. For the political and intellectual Italian, the violence in the power takeover was not an irreplaceable condition proposed by Marx, just as Marx had proposed that the law was the simple expression of the dominant class, that is why for Basso, the dialectic transformation of the bourgeois institutionality could generate the conditions for a complete transformation, it's to say, the construction of the revolutionary power.

There is a first discussion that underlies the affirmations of Basso, the discussion about strategy, beyond the political definitions of the parties that the Marxist social scientists adhered to, they had "scientific" arguments about the process. The theoretical interpretation allowed them to take several postures, and just like Basso proposed that violence was not intrinsic to transformation and that the change in the character of the State had to be "dialectic", there were others that were interpreting the theory in a different way, proposing the inevitability of violences.

In this line of thinking was Glauser, for him there was no possibility of developing a revolution from the inside of a bourgeois structural frame, since this structure limited the fight for power and thus, the transition to socialism. Although the Chilean process was in transition to a revolution, this transition at some point had to convert into a jump where the working class would take the power. Glauser said, "the popular forces want to respect the forms of bourgeois law, because now those forms have become a revolutionary weapon in the hands of the Popular Government. But, the possibility that this would effectively happen does not rely only in the popular forces, but in the resistance capacity that the enemy has, that this, once escaping the law, would have or would not have enough strength to break the institutional and juridical order" (Glauser, 1972).

For the intellectual MAPU follower, violence was not absent in the process but was dependent on the real forces that had reactionary sectors in respect to the consolidation of the Unidad Popular. He pointed out that if the popular process was consolidated, the bourgeois would be obliged to act outside of the institutionality through the violence. It was urgent then to achieve the transformation of the character of the State, likewise the character of the police and armed forces so that they would not become an instrument in service to the bourgeois, affirming that "the socialist transition would not really begin unless there was an effective and decisive change in the character of the State, while the proletariat had not totally succeeded in the battle for power" (Glauser, 1972: 42).

\footnotetext{
${ }^{5}$ Despite the importance of Cuba, for the social scientists of the revolutionary left-wing, it was not an option in Chile, the MIR, MAPU and the revolutionary socialists ascribed to the construction from the basis of spaces of People Power.
} 
The historical tension that the Chilean reality faced would allow the critical reading of Lenin and $\mathrm{Marx}^{6}$ without deviating from the fundamental conclusions of these referents, up to this point there is no fundamental contribution to the theory of Power and State, but rather a different positioning about the affirmation that Lenin pointed out, that the State is always a product and reflex of class contradictions (Lenin, 1917), therefore, in order for the State become an organ of service to the people, it must change its class character first.

In these general lines of possibility and restriction of the State in the development of the socialist revolution, the rest of the interventions of Rossana Rossanda, Marta Harnecker and Antonio Viera Gallo were generated ${ }^{7}$.

Harnecker, a militant of the Socialist Party, one of the parties that formed part of the Unidad Popular and disciple of Althusser, was dedicated mainly to theoretical were themes where the analysis of the reality through Marxism was the center. Unlike other intellectuals, Marta Harnecker did not perform an analysis of the popular sectors itself, her studies were more in the field of superstructure and theory, which did not imply the creation of a new theory of power, but an analysis of the existing theory in the light of national events. Her presentation analyzed in the seminar received the title: "El problema teórico de la transición" (The theoretical problem of the transition), and in this speech she responded to the interventions of Rossanda, Basso and Sweezy, subjecting them to scrutiny of the "correct" interpretation of Marxism without making any concrete reference to the national political conditions, but tried to define what the characteristics of the method of production were in transition ${ }^{8}$.

\footnotetext{
${ }^{6}$ The references to Marx are more recurrent than the references to Lenin in the academic texts, today this result may seem obvious, but in the period of time studied, the research topics were full of political statements and orientations. Someone who did not avoid the topic was the MAPU follower and sociologist affiliated to the CEREN, Tomás Moulian, who in the number 13 of the Cuadernos de la Realidad Nacional published an article with the title: Acerca de la lectura de los textos de Lenin, una investigación introductoria (About the morals of Lenin's texts: an introductory research). In this text, Moulian affirms that the morals of Lenin's works are theoretical or pragmatic "deviations" that he tries to correct by analyzing peasantry in concrete historical processes.

${ }^{7}$ A synthesis of the theoretical-political discussion given during the Unidad Popular en "El gobierno de Allende y la lucha por el Socialismo en Chile" (Allende's government and the fight for Socialism in Chile). In it write those who formed the organic intellectuality that we have made reference to: Álvaro Briones, Pío García, Jaime Osorio, Pedro Vuskovic, Eduardo Novoa, Jorge Witker, Clarisa Hardy, Rosa Neubauer y Theotonio Dos Santos (Briones et al., 1976).

${ }^{8}$ Theotonio Dos Santos, in an interview done in 2013 by the person who writes the present article said: "Group was formed apart [from the capital interpretations] with the influence of Althusser, that they read from behind, after the front. [...] the mentality of Althusser was very little dialectic, he wanted to put on one side the theoretical part and on the other the empirical instead, Marta worked very much in is this area and shaped many people; she gave various classes."
} 
The debates about power and popular participation were not new since in 1967, under the government of Eduardo Frei, a seminar was developed entitled "Seminario Internacional Visión Comunitaria del Estado" (International Seminar on the Communitarian Vision of the State), a meeting were representatives of the Christian Democracy of Panama, Venezuela, Bolivia, Uruguay and El Salvador participated, introducing to the Latin American State in the process of transition from a state product of an individualist society towards a communitarian society.

Independent of the different positions that existed among the Marxist social scientists, all of them started with some basic assumptions: Chile was moving towards socialism, there was a violent conservative reaction and that, despite the changes, there was a continuity of the bourgeois characteristics of the State.

These statements were supported by the academic publications of these intellectuals, among them for example, the book "Chile Hoy" that compiled a series of studies about the social-economic reality of the country, as well as in the journals of the study centers such as "Desarrollo y Sociedad", "Cuadernos de la Realidad Nacional" or "Cuadernos del Ceso". In these publications, although we can not find a new theory of State or power, we can find the contributions from the theory of dependency made by several Marxist social scientists residing in Chile. That meant new interpretations and definitions about the social formation of Latin America and Chile, starting from these new conceptions they were contributing to the unique description of the composition of power in Chile, if the State was the product and reflection of the class contradictions, what shape would the class contradictions adquire in the country? What was the particularity of the State in Chile? The research that we have discussed were developed in work groups and were oriented under specific themes, some of them are reviewed in the following chart $^{10}$.

\footnotetext{
${ }^{9}$ Pinto, Aníbal y otros. Chile Hoy. Santiago, Chile: Siglo XXI, 1970.

${ }^{10}$ For example, Viera Gallo related to issues of legality and public institutionality in the document "Materiales para el estudio del área de propiedad social" (Materials for the study of the area of social property), a text with headline "sobre la legislación que define las tres áreas de la economía (About the legislation that defines the three areas of the economy) of the same year in December the following would be published "The second road towards socialism: institutional aspects". Cuadernos de Realidad Nacional, Nº 11, January 1972.
} 


\section{Research Groups in CESO and CEREN}

\begin{tabular}{|c|c|c|}
\hline Institutional affiliation & Research area & Name of the researchers \\
\hline CESO & $\begin{array}{l}\text { Dependency and } \\
\text { Development }\end{array}$ & $\begin{array}{l}\text { Theotonio Dos Santos, } \\
\text { Orlando Caputo, Sergio } \\
\text { Ramos, Roberto Pizarro, } \\
\text { José Martínez. }\end{array}$ \\
\hline CEREN & Communications & $\begin{array}{l}\text { Armand Mathelart, } \\
\text { Michelle Mathelart, Mabel } \\
\text { Piccini. }\end{array}$ \\
\hline CESO & $\begin{array}{l}\text { University and Student } \\
\text { Movement }\end{array}$ & $\begin{array}{l}\text { Tomás Amadeo Vasconi, } \\
\text { Inés Reca, Guillermo } \\
\text { Labarca. }\end{array}$ \\
\hline CEREN & $\begin{array}{l}\text { Economy, Dependency and } \\
\text { Class Relationships }\end{array}$ & $\begin{array}{l}\text { Frank Hinkelammert, } \\
\text { Manuel Antonio Garretón, } \\
\text { Patricio Biedma, Kalki } \\
\text { Glausser, Hugo Perret. }\end{array}$ \\
\hline CESO & $\begin{array}{l}\text { Rural Business of the } \\
\text { Farms in the Central Valley }\end{array}$ & $\begin{array}{l}\text { Alexander Schejtman, } \\
\text { Gonzalo Izquierdo, Tomás } \\
\text { Godoy, Silvia Hernández. }\end{array}$ \\
\hline CESO & The Industry in Chile & $\begin{array}{l}\text { Marcelo Carmagnani, } \\
\text { Laureado Ladron de } \\
\text { Guevara, Teodoro Álvarez, } \\
\text { Vania Bambirra,Víctor } \\
\text { Brodersohn. }\end{array}$ \\
\hline CEREN & $\begin{array}{l}\text { Politics, Institutionality, } \\
\text { Law }\end{array}$ & $\begin{array}{l}\text { Tomás Moulian, José } \\
\text { Antonio Viera Gallo, } \\
\text { Norbert Lechner, Hernán } \\
\text { Villablanca, Patricio } \\
\text { Biedma. }\end{array}$ \\
\hline
\end{tabular}

Chart of own construction on the basis of the data published in the "Boletion del Ceso" and "Cuadernos del Ceso". The data refering to the CEREN were extracted from Rivera (2015).

For this historical cycle, perhaps one of the major contributions about the characterization of the Chilean State is that given by René Zavaleta Mercado, an intellectual and Bolivian residing in Chile since $1971^{11}$.

${ }^{11}$ Related with the previous paragraph, Zavaleta structures his arguments discussing the text of Sergio Ramos, Chile una economía en transición (Chile an economy in transition), where even though Ramos does not develop a theory about the State, in practice his definitions about the 
Zavaleta had already published in 1964 an analysis about Dual Power and the experiences of the Bolivian Revolution of 1952. This fundamental study would be the basis for the analysis that would be done by the CEREN about Chilean society. This Bolivian social scientist contributed to the power theory, proposing a characterization of the Chilean state that allowed, in his opinion, to explain the limits in the construction process of People Power. For Zavaleta, the Chilean state was characterized by its hypertrophy, transforming institutionality into something decisive in the development of social processes, pointing out that Chile was a country with a social and economic level that was not correlated with the enormous level of development of institutionality (Zavaleta, 1974).

\section{THE CONTRIBUTION OF THE INTELLECTUALS, THE SYSTEMATIZATION AND DISCUSSIONS ABOUT PEOPLE POWER IN CHILE}

The intellectuals and politicians of the new left-wing party compared the Chilean process with that already experienced by the Russians and tried to take lessons from the Leninist analysis about the existence of a duality of power: the one from the State, that still kept the capitalist character, and the one from the people, that tried autonomous ways of participation and that competed with the State for legitimacy in leading the way towards socialism. In parallel to the theoretical discussions that the left-wing intellectuals were carrying out in Chile, there were also more concrete analyses based on the events that were happening during the government of the Unidad Popular, the analysis and interpretation of the tensions gave arguments to validate the strategy that these militant intellectuals ascribed to. A platform to spread these analyses and interpretations was the magazine Chile Hoy ${ }^{12}$.

In the first issue published in June 1972, the economist who ascribed to the CESO, Pío García, proposed that the Unidad Popular had not succeeded in translating social achievements into electoral triumphs and that the support that the government mustered was far away from any degree of organization. In the same publication and a year after the victory of Allende, Marta Harnecker conducted an analysis of the trajectory of the Unidad Popular and a balance of the improvements and setbacks of the government in the struggle to attain power.

transition towards Socialism forced him to refer to power, reaching a conclusion that in Chile during Unidad Popular there existed a duality of power, expressed in the maintenance of the domination of the State by the bourgeois, but making it part of the workers, that part would be the Executive Power.

${ }^{12}$ For a more specific description of this magazine see: (Lozoya, 2013). 
In the article she divided the period into cycles where the first four ones -that started in September 1970 to June 1972- were described as interspersed victories for the Unidad Popular and the right-wing party hampering the hegemony for one of the forces. This revealed the lack of leadership in the left-wing party and the impossibility of the right-wing to present a more accurate offense. The fifth step identified by Harnecker -that started September 4th 1972- was characterized by the progress of the popular forces triggered by the rise of movements in the sectors that supported the Unidad Popular. The sociologist from the CESO pointed out that: "this period is marked by big and combative popular movements and by the strengthening of the unity of the parties of the Unidad Popular. The rightwing party seems forced to leave its coup planes, replacing them with insurrection plans to overthrow the government [...] although the first offensive of the Unidad Popular seems to occur mainly from the superstructural levels, all the remaining offensives have been directly linked to the revolutionary potential showed mainly by the mobilized working class [...] its instinct, its consciousness, its pugnacity have been way over the political leadership carried out by the Unidad Popular"13.

Thus, Harnecker recognized the limits of her own collectivity for agreeing to coordinated actions with the rest of the political forces of the coalition, which resulted in the popular movement surpassing the leadership that they tried to make. Then, the fight for power was in the hands of the people.

Besides the theorizations carried out by the intellectuals, up to this point it was not possible to notice a definition of Power. There are no clear signs about what level of control the state apparatus should have over the popular sectors for talking about Power and Revolutionary State and the parties' role in this takeover process was not clear. What exactly does it mean to takeover the state apparatus? In regards to the intellectual militants of the left-wing revolutionary party, did they recognize the mediation between the people and the power? Or, when they referred to the people taking the power, they meant it literally?

The counterpart of the State power was People Power, but in this respect the Chilean situation was not the same as that the Russian reality in the February Revolution, the grassroot organizations of the Chilean society were not similar with those of the soviets. The People Power in Chile, in the opinion of the same revolutionary intellectuals, was in construction and lacked organization and leadership even though it was potentially the manager of the revolution.

While for every revolutionary the basis of the People Power was the organization of the workers, some organizations like the MIR supplemented this definition with the call for the organization and revolutionary movement of

${ }_{13}$ Marta Harnecker, Fuerzas en pugna, in Chile Hoy, No 21, year 1. 3-9 of November, 1972. Available in Socialismo Chileno. www.socialismochileno.cl 
the poor from the countryside and the city. Thus, these intellectuals committed analytical and theoretical efforts for characterizing those who formed part of this People Power.

For the MIR, those who were part of it where those representatives of the poor that up until that moment had been analyzed from the orthodox Marxism perspective or from the theory of marginality. The intellectuals of the new left-wing now had the possibility to analyze their actions in situ, in the full articulation process and conformation of the People Power. The problem was that those which the intellectuals and militants called People Power, in the end would turn into a instinctive coordination with low levels of organizational ability, with precarious material conditions for the resistance to counter-revolution and with a conscious development that was clearly an overestimation of those who had observed their actions.

During that time, the characterization that the social scientists did of the popular sectors showed them as subjects that represented the objective conditions of the Chilean social formation, social formation that they themselves had dedicated large efforts into characterizing while at the same time trying to elaborate a theory that projected the revolutionary action that these characters had described ${ }^{14}$. These left-wing intellectuals analyzed the subjects under the Marxist paradigm but hoped to elaborate their own theory for the Chilean revolution. So, in its role as the intellectual and political forefront, they observed and collected the lessons of the ongoing process and elaborated a theory from the practice

The studies of the sociologist from the CESO and militant of the MIR, Silvia Hernández, were part of those efforts. The analysis and interpretations of Hernández accounted for the advancement of capitalism in Chilean agriculture and contradicted those visions that proposed that land was a space of feudal production relations. This characterization created the opportunity to affirm the possibility of organizing the rural proletariat and forming spaces of power in the farms. Deepening the collective action, the Argentinean sociologist working in the Universidad de Concepción and ICIRA, and also a militant of the MIR, Juan Carlos Marín, carried out a study about the radicalization of the fight for land, which gave rise to a book published in 1973 with the title "las Tomas", in which

\footnotetext{
${ }^{14}$ An example of these are the articles published in the $\mathrm{N}^{\circ} 3$ of the journal CESO Desarrollo y Sociedad, "El desarrollo capitalista del campo chileno" by Silvia Hernández, "El rol de los sectores agrícolas y la estructura de clases en Chile" by Sergio Gómez; in No 2 CESO bulletin, "El empresariado chileno: algunas orientaciones generales para su estudio" by Víctor Brodershon; Cuadernos de la realidad Nacional No 14, "Estructura agraria y consejos comunales campesinos: situación actual, análisis y estrategia" by Eugenio Maffei y Emilio Marchetti. No 11 "Poder popular en el agro chileno" by Wilson Cantoni, No 10 "Poder obrero y campesino y transición al socialismo en Chile" by Jorge Larraín y Fernando Castillo, No 5 "Sindicato campesino" by Almino Affonso, as examples.
} 
Marin analyzed the structural conditions that gave rise to the fight for the property of land, but also, and especially, the organizational forms and collective actions developed by these subjects.

In regard to the urban world, the Peruvian psychologist Carmen Pimentel carried out a study published in 1973 with the name "Vidas marginales", where she analyzed the ordinariness of the marginal Chilean populations; this book had a prologue by the intellectual, also Peruvian, Aníbal Quijano, where he vindicated the occupation actions and autonomy performed by Chilean settlers and argued that the construction and defense actions of that autonomous reality planted a seed of People Power (Pimentel, 1972).

In a even more direct relationship with the forming process of People Power by his direct participation in the neighborhood organization was Nestor D'Alessio. This Argentinean sociologist had worked in the Di Tella Institute, and along with Juan Carlos Marín, had taken part of the marginality project, first in Argentina and then in Chile. The group in Argentina also included José Nun, Miguel Murmis, Ernesto Laclau, among others (Petra, 2008). He came to Chile in 1969, joining the Universidad de Concepción as a professor in the Sociology program, where he was designated as Department Director in 1971. From this space of the intellectual elite, he was organically linked with the MIR and he directly intervened in the spaces of social construction in the city of Concepción, among them, in the People's Assembly (D'Alessio, interview 2016).

Beyond the creation of the Popular Assembly or People's Assembly and the coordinated action of the workers from the Área de Propiedad Social (Area of Social Property) implemented by Vuscovic from the government, the discussions among the social scientists about the duality of power became more recurrent, mostly because each time the conservative reaction was becoming more evident and decisive, and because from the inside of the government this was seen with mistrust.

Pío García, Theotonio Dos Santos and Ruy Mauro Marini investigated the Chilean situation in the journal Chile Hoy in August 1972. Dos Santos analyzed the duality of powers, proposing that its existence in history always meant the overcoming of the left-wing party. He valued the process of the Unidad Popular since "the existence of a popular government allows that this People Power can be supported from above, to be legitimized and to be, finally, legalized through a parliamentary majority, that creates a new type of people's assembly, that might be constituted in great part by deputies or representatives of these new forms of power" ${ }^{15}$.

Meanwhile in April 1972, Ruy Mauro Marini stated that the educational proposal of the government should be implemented through the creation of Local

\footnotetext{
${ }^{15}$ Dos Santos, El debate Sobre el Poder. Nuevos elementos. Chile Hoy Año $1 \mathrm{~N}^{\circ} 8$ semana del 4 al 10 de agosto 1972. pág. 4. Available in Socialismo Chileno. www.socialismochileno.cl.
} 
Councils of Education to avoid the sabotage of the right-wing party towards the initiative. For the proletariat organization, this would mean "to extend its vanguardist role to another forefront in the battle of classes, from which not even one should be excluded from its vigilant and combative direction. It would mean, above all, to move forward in the process of creating the bodies of People Power" ${ }^{16}$. The intellectuals not only observed what was happening, but also imagined what should occur immediately.

These spaces of local power had as a background the instances of mobilization that were born in the early 60 s and were now becoming more massive in regards to land seizures and the self-construction of tenements by the settlers, of the country seizures, of the establishment of worker's organizational meetings in the companies of Área de Propiedad Social and the companies' seizures made by their own workers. Despite that the revolutionary intellectuals saw these actions and popular organization movements with very high approval, assigning them with high level political objectives and seeing them as expressions of power, in practice these were actions of popular claim for those basic social rights that had been denied throughout history except, maybe the trade union spaces, that did not have more complex objectives than the purely satisfying the "economistic" needs of the class.

Despite the enthusiasm of the intellectuals in the call to take the revolutionary leap and overcome institutionality, they did not reach the extreme taken by the leader of MIR, who in 1972 called to dissolve congress for being the principle trench of the dominant class and to replace it with a people's assembly. However, the commitment to People Power in the crisis of Allende's government faced a faction of the Socialist Party, the mirists with Communist Party visions and Allende himself in regards to the course of action that the events should take.

André Gunder Frank himself, researcher of the CESO, in 1972 presented in the Latin American Conference of Sociology a lecture titled "Dependence has died. Long live dependence and the class struggle", where he argued that although dependence was a reality, the usefulness of the theory for confronting the political process was limited, one had to pay attention to the class struggle in particular, and overall prepare for the reaction of the conservative forces (Frank, 1991).

For the Communist Party, the autonomous actions and People Power carried out by the MIR were no more than arguments delivered to the right-wing party and to imperialism to intervene and take a swing at the popular government, while for Allende -according to Theotonio Dos Santos- People Power should be the livelihood of the government and not the other way around. The interpretations about the means needed to fight for power were not compatible.

${ }^{16}$ Chile Hoy N ${ }^{\circ} 45$ Abril 1973 Available in Socialismo Chileno. www.socialismochileno.cl. 
After the military coup that ended not only with the government of Salvador Allende, but also any other kind of popular organization, the intellectuals that debated about process -in the process itself- made their assessments about the conditions of the struggle for power in Chile.

In 1974, already outside of Chile, Rudy Marini published "Dos Estrategias en el proceso chileno" (Two strategies in the Chilean process), in which, maintaining the discussion of the necessity of the revolutionary leap that he expressed in his texts in Chile Hoy, Marini answered to those like Darcy Ribeiro, that had blamed the "rave" left-wing for carrying out the actions of the People Power and for the defeat of Allende's government.

Ribeiro had published an article in Argentina where he pointed out: "what I saw was the best theorists -because they read more than that exegetical nonsense self-proclaimed by Marxism- wandering in Chile like they were on the moon, incapable of perceiving and understanding the revolutionary process that they had in front of them because of their blind eyes was trying for mere reformism [...] sighing for a revolution of pipe dreams that someday would fall on their heads" (Riveiro, 1974).

Marini responded that before the option of Allende respecting the bourgeois institutionality, the popular organizations should have acted to solve one of the fundamental problems -before assuming their own duties in the construction of socialism- which was seizure of power by the workers (Marini, 1976).

On the part of René Zavaleta, making a contrast with the situation lived in Bolivia, he described the exceptional characteristics of the Chilean reality, pointing out the existence of an hypertrophy of the state of which Allende tried to use to develop other aspects of the structure that did not had the same level of progress. In this task, according to Zavaleta, Allende did not have any counterpart. Zavaleta refuses the existence of a true Dual Power, although he recognizes that there was a relevant worker's organization. He points out that this did not have the mechanism to exert power or as a coercion apparatus because such power never existed (Zavaleta, 1974).

Meanwhile Dos Santos, in a seminar carried out in Mexico in 1975, proposed that: "in Chile, expressions of People Power were created so that they somehow looked to combine themselves with the existing bourgeois state and did not achieve -in that reality- to become a national alternative, but represented a tendency in that direction. [...] It was not possible to link both forces and maybe this would have been a way to earn legitimacy for the constitution of the popular militia, the legitimacy of support for the military sector was more radicalized to this new emerging power" (Dos Santos, 1975).

All of this while in Chile the organization for the projection and perspective of power was replaced by the organization for resistance. 


\section{CONCLUSIONS}

The Latin America of the 60s and beginnings of the 70s was a period where political and academic discussions shared the same spaces and on the other hand, from a series of contextual elements, generated a confluence of Latin American intellectuals in Chile. Even though they came from other countries, they possessed an internationalist and Latin Americanist approach to the current political process, consequently opinionating and acting shamelessly against the national situation.

These social scientists, most of them militant and with concrete political commitments, argued about the theory and practice of power, trying to obtain lessons from the processes experienced in other latitudes, but understanding that it was necessary to build their own-theory for the Chilean reality.

The discussions about the limits and possibilities of the bourgeois institutionality that hosted the revolutionary construction in Chile reached great relevance, mostly because the social scientists residing in different institutions of study, at a national level, felt responsible for the process and believed that, from their own specific areas, they should contribute clarity to the development of the popular government.

However, the contributions that those intellectuals made started from premises that at the end would turn out to be false. The first of them was that capitalism was in a terminal crisis and that Latin America was moving towards socialism, what needed to be defined was the strategy to reach it. The second one was that the popular organization that was built in that period occupied a space of power, but when in practice, could not overcome the demands.

When observing the organization practices and collective actions of the popular sectors, the intellectuals accomplished a systematization and conceptualization of them, additionally applying the Marxist and Leninist theory to define them while putting all their revolutionary hopes in its potential. However, as part of the intellectual and political forefront of that time, they were far away from being able to establish a proposal of how to solve the contradictions of the Chilean process. Either by inability, excess of optimism or because time did not play on their favor, the intellectuals that only stayed to observe (observational participant) what they called People Power and were only capable of noting the evident limits of the state that was managing the popular government, which was not achieving the task that they imposed on themselves: to contribute to the establishment of the revolutionary leap. 


\section{REFERENCES}

Aguilar, Alfonso. El gobierno de Allende y la lucha por el Socialismo en Chile. México: Ediciones UNAM, 1976.

Bambirra, Vania. Revolución Cubana una reinterpretación. Santiago, Chile: CESO- PLA, 1973.

Bambirra, Vania, López, Álvaro, Moleiro, Moises, Nuñez, Carlos, Cordoruna, Silvestre, Marini, Ruy Mauro y Zapata, Antonio. Diez años de insurrección en América Latina. Santiago, Chile: Ediciones Prensa Latinoamerican, 1971.

Dos Santos, Theotonio. Problema estratégicos y tácticos de la revolución socialista en América Latina. Seminario "El gobierno de Allende y la lucha por el socialismo en Chile”. México: UNAM, 1975.

Frank, André. El subdesarrollo del desarrollo. Un ensayo autobiográfico. Caracas: Editorial Nueva Sociedad, 1991.

Glauser, Kalki. "La legalidad en la transición al socialismo. Comentario a la intervención de Lelio Basso". En Varios Autores, Transición socialismo y experiencia chilena. Santiago, Chile: CESO-CEREN, Editorial PLA, 1972.

Lenin, Vladimir. El Estado y la Revolución. Madrid: Fundación Federico Engels, 1997.

Lozoya, Ivette. Debates y tensiones en el Chile de la Unidad Popular ¿La traición de los intelectuales? Pacarina del Sur, 5/17, 2013.

Marini, Ruy Mauro. Dos estrategias en el proceso chileno. En El reformismo y la contrarevolución. Estudios sobre Chile. México: Ediciones ERA, 1976.

Petra, Adriana. El "Proyecto Marginalidad": los intelectuales latinoamericanos y el imperialismo cultural. Politicas de la memoria, 8/9. Verano 2008/2009.

Picó, Josep y Pecourt, Juan. Los intelectuales nunca mueren. Una aproximación socio histórica (1900-2000). Barcelona: RBA, 2013. 
Pimentel, Carmen. Vidas Marginales. Santiago, Chile: Editorial Universitaria, 1972.

Pinto, Aníbal, Aranda, Sergio, Martínez, Alberto, Caputo, Orlando, Pizarro, Roberto, Faletto, Enzo, Ruiz, Eduardo, Chonchol, Jacques, Brodersohn, Víctor, Vasconi, Tomás, Reca, Inés, Dorfman, Ariel. Chile Hoy. Santiago, Chile: Siglo XXI, 1970.

Ribeiro, Darcy. "Allende y la izquierda Desvariada". La Opinión Cultural, Buenos Aires, 1974. Recuperado de: http://www.salvadorallende.cl/biografia/ testimonios/legados47.PDF.

Rivera, Carla. 2015. "Diálogos y reflexiones sobre las comunicaciones en la Unidad Popular. Chile 1970-1973”. Revista Historia y Comunicación social, 20 /2.

Varios Autores. Transición al socialismo y experiencia chilena. Santiago, Chile: CESO-CEREN, Editorial PLA, 1972.

Zavaleta, René. Poder Dual en América Latina. México: Editorial siglo XXI.

\section{Magazines:}

Chile Hoy http://www.socialismo-chileno.org/ChileHoy/chile_hoy.html.

Cuadernos de la realidad Nacional http://www.socialismo-chileno.org/Ceren/ceren. html.

Boletin del CESO.

Cuadernos del CESO.

Revista Desarrollo y Sociedad.

\section{Interviews:}

Theotonio Dos Santos, junio 2013.

Nestor D’ Alessio, diciembre 2016. 